\title{
Serving Our Country
}





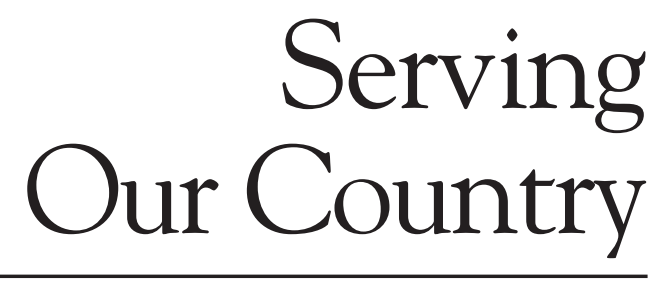

Japanese American Women in the Military during World War II

BRENDA L. MOORE 


\section{Library of Congress Cataloging-in-Publication Data}

Moore, Brenda L., 1950-

Serving our country : Japanese American women in the military during World War II / Brenda L. Moore.

p. $\mathrm{cm}$.

Includes bibliographical references and index.

ISBN 0-8135-3277-9 (cloth : alk. paper) - ISBN 0-8135-3278-7

(pbk. : alk. paper)

1. United States. Army Women's Army Corps-History. 2. World War, 1939-1945-Participation, Japanese American. 3. Japanese-American women-History. 4. Women soldiers-United States. 5. United StatesEthnic relations. I. Title.

UA565.W6 M66 2003

$940.54 ' 04-\mathrm{dc} 21$

British Cataloging-in-Publication information is available from the British Library.

Copyright (C) 2003 by Brenda L. Moore

All rights reserved

No part of this book may be reproduced or utilized in any form or by any means, electronic or mechanical, or by any information storage and retrieval system, without written permission from the publisher. Please contact Rutgers University Press, 100 Joyce Kilmer Avenue, Piscataway, NJ 08854-8099. The only exception to this prohibition is "fair use" as defined by U.S. copyright law.

Manufactured in the United States of America 
This book is dedicated to the memory of my parents, Hester W. Moore, December 12, 1929-February 9, 2002 Albert Moore, October 12, 1926-December 10, 1968 
